\title{
Domestic Market Integration and the Law of One Price in Brazil
}




\title{
WP/15/213
}

\section{IMF Working Paper}

\section{Domestic Market Integration and the Law of One Price in Brazil}

\author{
by Carlos Góes and Troy Matheson
}

IMF Working Papers describe research in progress by the author(s) and are published to elicit comments and to encourage debate. The views expressed in IMF Working Papers are those of the author(s) and do not necessarily represent the views of the IMF, its Executive Board, or IMF management.
I N
N T E R N A T I O N A L
$M O N E T A R Y$
$F \cup N D$ 


\title{
IMF Working Paper
}

Western Hemisphere Department

\section{Domestic Market Integration and the Law of One Price in Brazil Prepared by Prepared by Carlos Góes and Troy Matheson}

Authorized for distribution by Alfredo Cuevas

September 2015

\begin{abstract}
IMF Working Papers describe research in progress by the author(s) and are published to elicit comments and to encourage debate. The views expressed in IMF Working Papers are those of the author(s) and do not necessarily represent the views of the IMF, its Executive Board, or IMF management.
\end{abstract}

\begin{abstract}
This paper presents the first assessment domestic market integration in Brazil using the law of one price. The law of one price is tested using two panel unit root methodologies and a unique data set comprising price indices for 51 products across 11 metro-areas. We find that the law of one price holds for most tradable products and, not surprisingly, non-tradable products are found to be less likely to satisfy the law of one price. While these findings are consistent with evidence found for other countries, price convergence occurs very slowly in Brazil, suggesting relatively limited domestic market integration.

JEL Classification Numbers: E37, F15, O54.

Keywords: Law of One Price, Panel Cointegration, Domestic Market Integration.

Author's E-Mail Address: cgoes@imf.org, tmatheson@imf.org
\end{abstract}




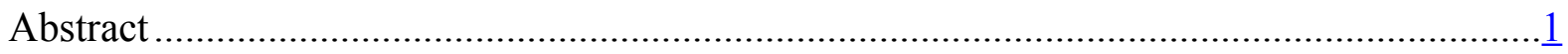

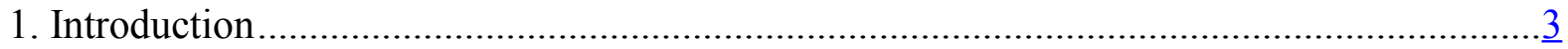

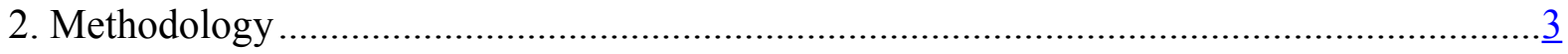

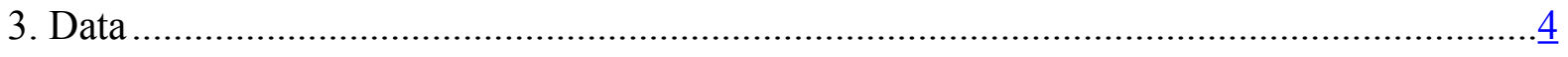

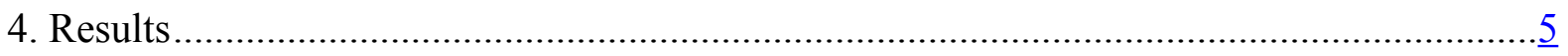

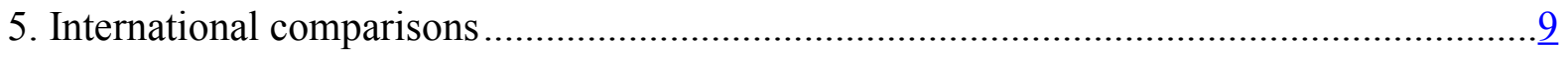

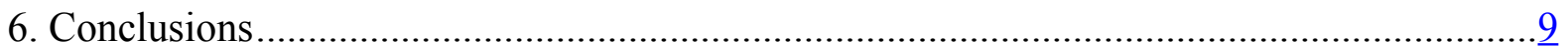

Tables

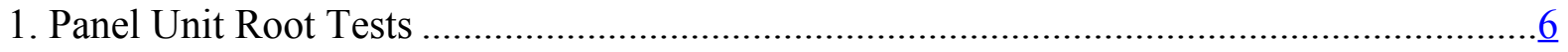

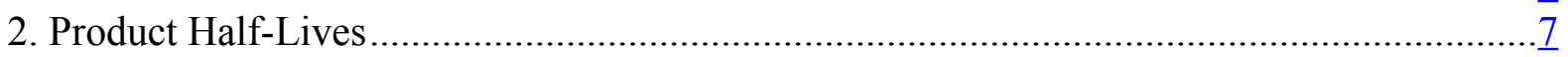

Figures

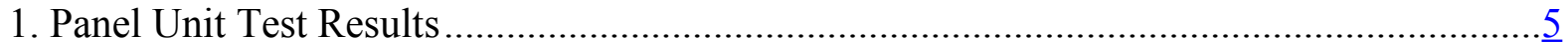

2. Distribution of ADF coefficients ........................................................................... $\frac{8}{8}$

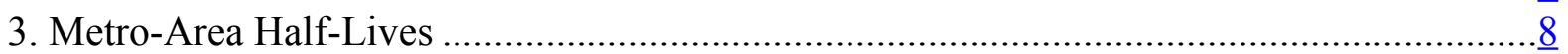

4. Reaction Functions of Price Dispersion ........................................................................

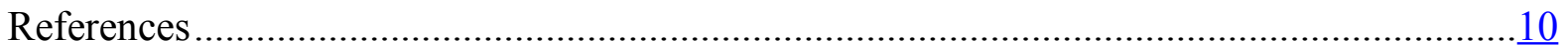




\section{INTRODUCTION}

Brazil is the fifth largest country in the world by population and landmass and has the seventh largest economy. Yet little is known about the extent of domestic market integration in Brazil. Recent research has shown that Brazil has relatively poor infrastructure (cf. Garcia-Escribano, Góes, and Karpowicz, 2015) suggesting that there are significant barriers to intra-regional trade and limited domestic market integration.

In this paper, we examine domestic market integration in Brazil using the law of one price for the first time. Since the seminal work by Parsley and Wei (1996), the use of a panel unit root methodology to investigate the prevalence of the law of one (LOOP) on intra-country trade has increased (see, for instance, Li and Huang, 2006, and Fan and Wei, 2006). An overwhelming majority of the literature finds that the LOOP holds within countries. We extend the literature by assessing price convergence within Brazil for 51 products (33 tradables and 19 non-tradables) across 11 metro-areas over 14 years.

Two recent panel unit root testing methodologies (Levin, Lin, and Chu, 2002, and Im, Pesaran, and Shin, 2002) suggest that LOOP holds for most tradable products in Brazil and, not surprisingly, non-tradable products are found to be less likely to satisfy LOOP. While these findings are similar to other studies, we find that price convergence occurs relatively slowly, suggesting limited domestic market integration.

\section{Methodology}

If goods markets are fully integrated, then the difference between the (log) price levels for a tradable product in different cities should be stationary. This implies that there should be co-integration for all pairs of cities $i$ and $j$ : algebraically, $\left.p_{i t}-p_{j t}\right) \sim I(0) \forall i, j$ or, equivalently, $\left(p_{i, t}-\bar{p}_{t}\right) \sim I(0) \forall i$, with $\bar{p}_{t}=N^{-1} \sum_{i=1}^{N} p_{i, t}$. If $p_{i, t}^{*}=\left(p_{i t}-\bar{p}_{t}\right) \sim I(0) \forall i$, then $p_{i, t}^{*}$ is stationary, $p_{i, t}$ is cointegrated, and the LOOP holds.

Two panel unit root tests that build on the Augmented Dickey-Fuller (ADF) framework are used, Levin and others (2002) and Im and others (2002), henceforth, LLC and IPS, respectively. The most important difference between these two methodologies is that LLC impose the parameter of interest $\rho$ (defined below) to be same for all individuals, while IPS relax this assumption.

Both methods start by estimating individual ADF equations using time-effect-treated price indices $p_{i, m, t}^{*} \equiv p_{i, m, t}-\bar{p}_{m, t}$ for every city $i=[1,2, \ldots, 11]$ and product $m=[1,2 \ldots, 51]$. For each product $m$, the basic model is: ${ }^{1}$

$$
\Delta p_{i, m, t}^{*}=\tilde{c}_{i, m}+\sum_{k=1}^{K_{i, m}} \phi_{i, m, k} \Delta p_{i, m, t-k}^{*}+\left(\rho_{i, m}-1\right) p_{i, m, t-1}^{*}+\eta_{i, m, t}
$$

\footnotetext{
${ }^{1}$ In this paper, the lag length $k$ is determined using the Akaike information criterion separately for each equation.
} 
The LLC framework uses two auxiliary regressions to dissipate individual-specific dynamics:

$p_{i, m, t}^{*}=\hat{\alpha}_{1, i, m}+\sum_{k=1}^{K_{i, m}} \phi_{i, m, k} \Delta p_{i, m, t-k}^{*}+\hat{e}_{i, m, t}$
$\Delta p_{i, m, t-1}^{*}=\hat{\alpha}_{2, i}+\sum_{k=1}^{K_{i, m}} \phi_{i, m, k} \Delta p_{i, m, t-k}^{*}+\hat{v}_{i, m, t-1}$

and takes the averaged residuals of (1) to standardize $\hat{e}_{i, m, t}$ and $\hat{v}_{i, m, t}$, resulting in $\tilde{e}_{i, m, t}$ and $\tilde{v}_{i, m, t}$. The panel model is then estimated to calculate an asymptotically-normal Z-statistic, that is:

$$
\begin{aligned}
& \tilde{v}_{i, m, t}=\left(\rho_{i, m}-1\right) \tilde{e}_{i, m, t-1}+\xi_{i, m, t}, \quad \rho_{i, m}=\rho_{m} \forall i \\
& t_{\rho_{N T}}=\left[\left(N^{-1} \sum_{i=1}^{N} \xi_{i, m, t}^{2}\right) \sum_{i=1}^{N} \sum_{t=2+K_{i, m}}^{T} \tilde{e}_{i, m, t-1}^{2}\right]^{-\frac{1}{2}} \sum_{i=1}^{N} \sum_{t=2+K_{i, m}}^{T} \tilde{e}_{i, m, t-1} \xi_{i, m, t} \\
& Z^{L L C}=v^{-\frac{1}{2}}\left(t_{\rho_{N T}}-\mu \sqrt{N}\right)
\end{aligned}
$$

where with $\mu$ and $v$ can be found in LLC.

Similarly, following IPS, (1) is estimated and individual t-statistics for $i$ cross sections are calculated and used to compute an asymptotically-normally-distributed panel $Z_{t-b a r}$ statistic. Autoregressive parameters $\rho_{i, m}$ are allowed to vary individually. The $Z_{t-b a r}$ statistic is:

$$
Z_{t-b a r}=\frac{\sqrt{N}\left(N^{-1} \sum_{i=1}^{N} t_{i, m}-N^{-1} \sum_{i=1}^{N} E\left[t_{i, m} \mid \rho_{i, m}=1\right]\right)}{\sqrt{N^{-1} \sum_{i=1}^{N} \operatorname{Var}\left[t_{i, m} \mid \rho_{i, m}=1\right]}}, \quad \rho_{i, m}\left(\bar{\rho}, \sigma_{\rho_{i, m}}^{2}\right)
$$

where $E\left[t_{i, m} \mid \rho_{i, m}=1\right]$ and $\operatorname{Var}\left[t_{i, m} \mid \rho_{i, m}=1\right]$ can be found in Im and others (2002).

For those processes that are not explosive, half lives $h_{i, m}$ are computed from the individual ADF regressions (1) and the pooled (4):

$$
h_{i, m}=\frac{\ln (0.5)}{\ln \left(\left|\rho_{i, m}\right|\right)},\left|\rho_{i, m}\right|<1 \forall i
$$

\section{DATA}

We constructed a new dataset of price indices for 51 products categories across 11 metro-areas using extended CPI (IPCA) microdata; the original data were seasonally adjusted monthly percent changes, which we transformed into price indexes. We then used CPI weights to construct indices for the 51 product categories we analyze. Our original sample starts in August 1999, when the inflation targeting regime begins. After transforming the data, however, we dropped first 18 months to avoid potential bias from the fact that all price indices arbitrarily have the same value by the beginning of the sample. After such adjustments, the final sample ranges from January 2002 to July 2014. 


\section{RESUlts}

The empirical evidence in support for domestic market integration in Brazil is mixed at best. While LOOP seems to hold for most tradable products, the speed of convergence towards the national long-run trend is very slow.

Figure 1 below summarizes the aggregate results, after categorizing the 51 products as being either tradable or non-tradable. At the 10 percent significance level, using IPS, we reject the null hypothesis of a unit root for almost 70 percent of tradable products, while LLC rejects the null hypothesis for just under half of all tradable products. Despite (expected) divergences in rejection rates due to methodological differences, the results are broadly consistent: both LLC and IPS suggest that non-tradable product prices tend to have unit roots more frequently than tradable product prices. Table 1 details the product-specific p-values for both tests.

\section{Figure 1: Panel Unit Root Tests Results}

(percent rejection of null hypothesis of a panel unit root under different levels of significance, per methodology)

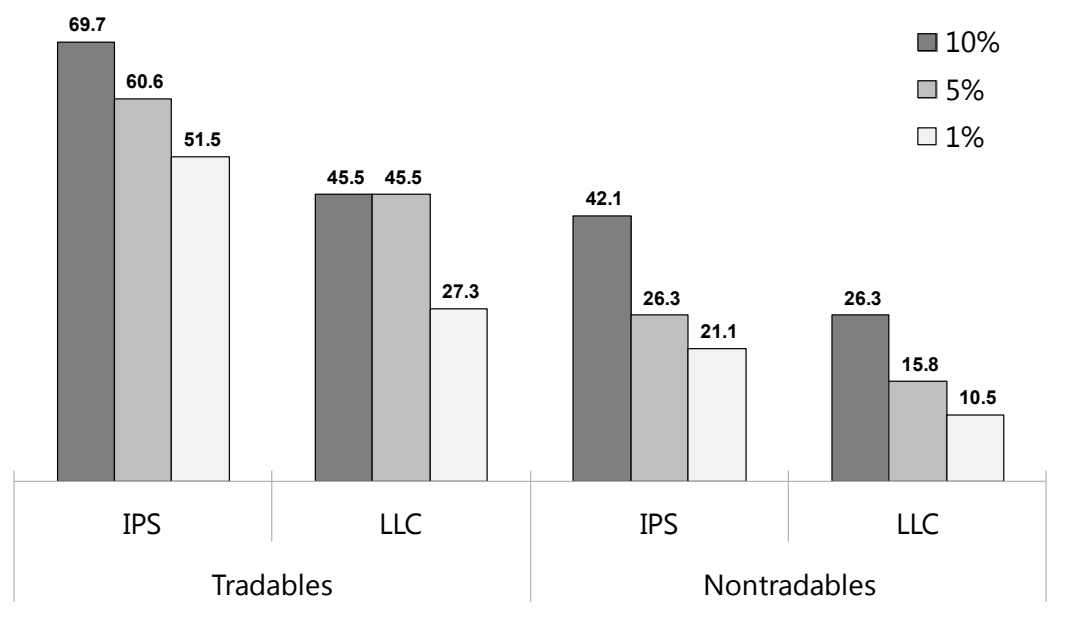


Table 1. Panel Unit Root Tests

\begin{tabular}{|c|c|c|c|}
\hline & Description & $\begin{array}{c}\text { IPS } \\
\text { p-value }\end{array}$ & $\begin{array}{c}\text { LLC } \\
\text { p-value }\end{array}$ \\
\hline \multirow[t]{2}{*}{ Tradables } & Cereals, seeds and oilseeds & $0.000 * * *$ & $0.000 * * *$ \\
\hline & Flours and pasta & $0.001 * * *$ & $0.019 * *$ \\
\hline \multirow{4}{*}{$\begin{array}{l}\text { Correlation } \\
\text { of IPS \& LLC } \\
\text { p-values: }\end{array}$} & Tubers, roots and legumes & $0.000 * * *$ & $0.000 * * *$ \\
\hline & Sugars and derivatives & $0.000 * * *$ & $0.009 * * *$ \\
\hline & Vegetables & $0.000 * * *$ & $0.000 * * *$ \\
\hline & Fruits & $0.000 * * *$ & $0.000 * * *$ \\
\hline \multirow[t]{27}{*}{0.65} & Meats & $0.000 * * *$ & $0.001 * * *$ \\
\hline & Fishes & $0.058^{*}$ & 0.644 \\
\hline & Processed meat and fish & $0.043 * *$ & 0.491 \\
\hline & Poultry and eggs & $0.000 * * *$ & $0.000 * * *$ \\
\hline & Milk and dairy products & $0.000 * * *$ & 0.170 \\
\hline & Bakery products & $0.003 * * *$ & $0.031 * *$ \\
\hline & Oils and fats & $0.000 * * *$ & $0.020 * *$ \\
\hline & Beverages and infusions & $0.000 * * *$ & $0.047 * *$ \\
\hline & Canned and preserved foods & 0.484 & 0.210 \\
\hline & Salt and spices & 0.137 & 0.443 \\
\hline & Pre-cooked meals & $0.001 * * *$ & $0.017 * *$ \\
\hline & Cleaning chemicals & 0.623 & 0.622 \\
\hline & Fuels (domestic) & $0.000 * * *$ & $0.011 * *$ \\
\hline & Residential electricity & $0.003 * * *$ & 0.153 \\
\hline & Furniture & 0.626 & 0.641 \\
\hline & Utensils and ornaments & 0.568 & 0.288 \\
\hline & Bed, bath and table & $0.075^{*}$ & 0.632 \\
\hline & Domestic appliances & $0.080^{*}$ & 0.346 \\
\hline & $\mathrm{TV}$, stereos and computers & 0.137 & 0.315 \\
\hline & Menswear & $0.037 * *$ & 0.157 \\
\hline & Women's clothes & 0.323 & 0.607 \\
\hline & Children clothes & $0.034 * *$ & 0.207 \\
\hline & Shoes and accessories & 0.175 & 0.725 \\
\hline & Jewelry & 0.896 & 0.709 \\
\hline & Fabrics and haberdashery & 0.382 & 0.340 \\
\hline & Fuels (vehicles) & $0.000 * * *$ & $0.000 * * *$ \\
\hline & Tobacco & $0.000 * * *$ & $0.000 * * *$ \\
\hline \multirow[t]{2}{*}{ Nontradables } & Food away from home & 0.330 & 0.436 \\
\hline & Rent and fees & $0.087^{*}$ & $0.001 * * *$ \\
\hline \multirow{4}{*}{$\begin{array}{l}\text { Correlation } \\
\text { of IPS \& LLC } \\
\text { p-values: }\end{array}$} & Domestic repairs & $0.007 * * *$ & 0.129 \\
\hline & Repairs and maintenance & $0.001 * * *$ & 0.141 \\
\hline & Public transportation & $0.000 * * *$ & $0.093 *$ \\
\hline & Personal transportation & 0.562 & 0.740 \\
\hline \multirow[t]{13}{*}{0.82} & Pharmaceuticals & 0.201 & 0.647 \\
\hline & Optical products & 0.641 & 0.467 \\
\hline & Medical and dental services & 0.462 & 0.663 \\
\hline & Laboratory and hospital services & 1.000 & 0.991 \\
\hline & Health Plan & 0.857 & 0.502 \\
\hline & Personal hygiene & 0.610 & 0.506 \\
\hline & Personal services & $0.043 * *$ & $0.009 * * *$ \\
\hline & Recreation & 0.989 & 0.911 \\
\hline & Photography and filming & $0.050^{*}$ & $0.090 *$ \\
\hline & Courses & 0.645 & 0.910 \\
\hline & Reading material & $0.007 * * *$ & $0.020 * *$ \\
\hline & Stationery & 0.167 & 0.606 \\
\hline & Communication & $0.069 *$ & 0.387 \\
\hline
\end{tabular}

Null hypotheses: all cities have a unit root

Significant at the *** $1 \%$ level; ** 5\% level; * $10 \%$ level.

\section{CInternational Monetary Fund. Not for Redistribution}


Table 2 compares the simple average of the half-lives calculated from the individual ADF regressions (1) with the half-lives of the pooled LLC coefficients for each product. As expected, prices of tradable products converge faster than prices of non-tradable products. However, price convergence is very slow. Average half lives are about 14-16 months for tradable prices and about 20-27 months for non-tradable prices.

Table 2. Product Half-Lives

\begin{tabular}{|c|c|c|c|}
\hline & Description & $\begin{array}{l}\text { Simple average of } \\
\text { individual half-lives }\end{array}$ & LLC pooled half-lives \\
\hline \multirow{2}{*}{ Tradables } & Cereals, seeds and oilseeds & 7.34 & 7.16 \\
\hline & Flours and pasta & 20.81 & 21.88 \\
\hline Correlation: & Tubers, roots and legumes & 3.95 & 3.90 \\
\hline \multirow{2}{*}{0.83} & Sugars and derivatives & 7.46 & 7.28 \\
\hline & Vegetables & 3.87 & 3.76 \\
\hline Average & Fruits & 15.72 & 17.86 \\
\hline of individual & Meats & 6.12 & 5.86 \\
\hline half-lives: & Fishes & 18.14 & 17.75 \\
\hline \multirow[t]{2}{*}{14.02} & Processed meat and fish & 19.34 & 15.90 \\
\hline & Poultry and eggs & 10.63 & 10.39 \\
\hline $\begin{array}{l}\text { Average } \\
\text { of pooled }\end{array}$ & Milk and dairy products & 7.58 & 9.89 \\
\hline LLC & Bakery products & 14.87 & 13.28 \\
\hline half-lives: & Oils and fats & 12.12 & 13.64 \\
\hline \multirow[t]{20}{*}{16.13} & Beverages and infusions & 9.33 & 8.91 \\
\hline & Canned and preserved foods & 27.68 & 28.24 \\
\hline & Salt and spices & 18.15 & 22.28 \\
\hline & Pre-cooked meals & 6.27 & 3.03 \\
\hline & Cleaning chemicals & 20.13 & 27.13 \\
\hline & Fuels (domestic) & 13.93 & 10.41 \\
\hline & Residential electricity & 12.65 & 12.70 \\
\hline & Furniture & 25.23 & 34.24 \\
\hline & Utensils and ornaments & 23.49 & 31.94 \\
\hline & Bed, bath and table & 11.87 & 18.49 \\
\hline & Domestic appliances & 14.51 & 13.73 \\
\hline & $\mathrm{TV}$, stereos and computers & 13.67 & 28.04 \\
\hline & Menswear & 20.31 & 20.35 \\
\hline & Women's clothes & 14.27 & 33.66 \\
\hline & Children clothes & 13.86 & 14.31 \\
\hline & Shoes and accessories & 15.27 & 21.41 \\
\hline & Jewelry & 28.20 & NA \\
\hline & Fabrics and haberdashery & 14.68 & 28.70 \\
\hline & Fuels (vehicles) & 5.11 & 5.10 \\
\hline & Tobacco & 6.11 & 5.00 \\
\hline \multirow[t]{2}{*}{ Nontradables } & Food away from home & 20.45 & 23.14 \\
\hline & Rent and fees & 26.40 & 27.89 \\
\hline Correlation: & Domestic repairs & 12.03 & 34.43 \\
\hline \multirow[t]{2}{*}{0.57} & Repairs and maintenance & 12.72 & 12.46 \\
\hline & Public transportation & 11.61 & 11.60 \\
\hline Average & Personal transportation & 19.33 & 22.66 \\
\hline of individual & Pharmaceuticals & 17.93 & 23.54 \\
\hline half-lives: & Optical products & 19.85 & 37.28 \\
\hline \multirow[t]{2}{*}{19.93} & Medical and dental services & 22.48 & 35.98 \\
\hline & Laboratory and hospital services & 26.46 & NA \\
\hline $\begin{array}{l}\text { Average } \\
\text { of pooled }\end{array}$ & Health Plan & 20.90 & NA \\
\hline LLC & Personal hygiene & 23.89 & 25.27 \\
\hline half-lives: & Personal services & 21.44 & 20.99 \\
\hline \multirow[t]{6}{*}{27.14} & Recreation & 29.46 & 53.05 \\
\hline & Photography and filming & 15.14 & 16.01 \\
\hline & Courses & 21.90 & 34.89 \\
\hline & Reading material & 25.59 & 24.17 \\
\hline & Stationery & 8.06 & 24.05 \\
\hline & Communication & 22.96 & 34.05 \\
\hline
\end{tabular}


Figure 2 shows the distribution function of $\rho_{i, m}$ across tradable and non-tradable products. Tables 1 and 2 provide further evidence that the expected difference between the two groups holds. That is, larger share of non-tradable prices have explosive processes, and amongst those processes that are not explosive, non-tradable prices tend to have higher autoregressive parameters.

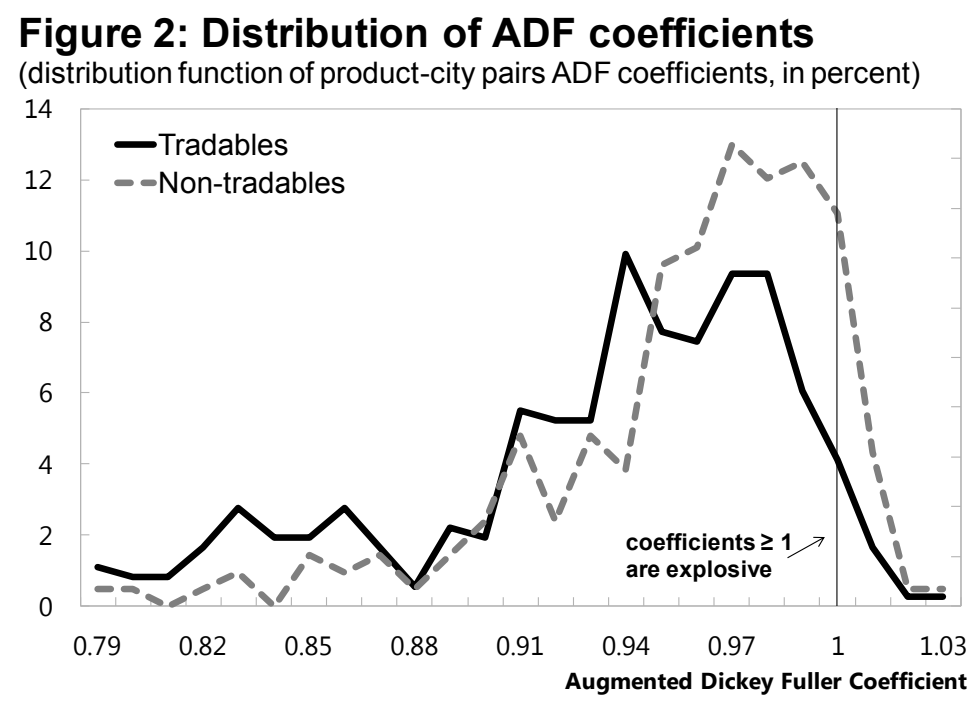

Figure 3 shows how the persistence of price level deviations varies across cities. Tradable price divergences range from a maximum of 17 months in Belo Horizonte to a minimum of 10.8 months in Curitiba. By contrast, non-tradable price divergences vary from 23.8 months in Salvador to 15.5 months in Belem. The standard deviation of half lives averages between cities is 2.3 and 2.7 months for tradables and non-tradables, respectively. There seems to be no overarching pattern in the distribution of half lives, suggesting a potential avenue for further research.

\section{Figure 3: Metro-Area Half-Lives (in months)}

$\square$ Tradables

$\square$ Non-tradables

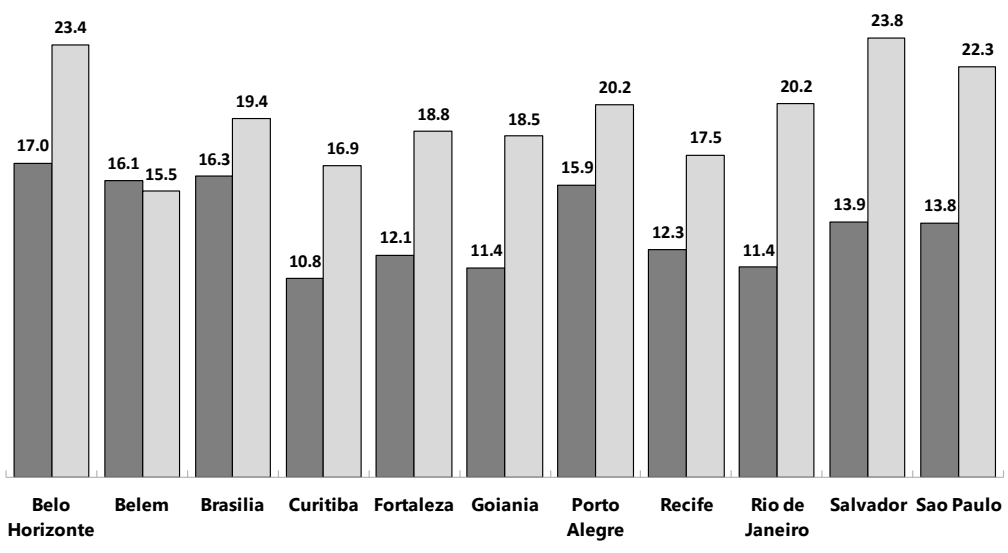




\section{INTERNATIONAL COMPARISONS}

While the literature generally supports LOOP within countries, estimated half lives of domestic price deviations vary significantly due to methodological differences. Our work is perhaps most comparable to that of Li and Huang (2006) and Fan and Wei (2006), who found evidence that LOOP holds domestically in Canada and China with monthly data. Average half-lives estimated for Canada and China are 4.72 and 2.35 months, respectively-much lower than we found for tradable products in Brazil (14-16 months).

Brazil's relatively slow price convergence is further illustrated in Figure 4, where we display derive the implied autoregressive terms for Canada, China, and Brazil using $|\rho|=$ $\exp (\ln (0.5) / h)$. For both in Canada and China more than $90 \%$ of price deviations are corrected within 18 months, but in Brazil the pace of convergence is much slower.

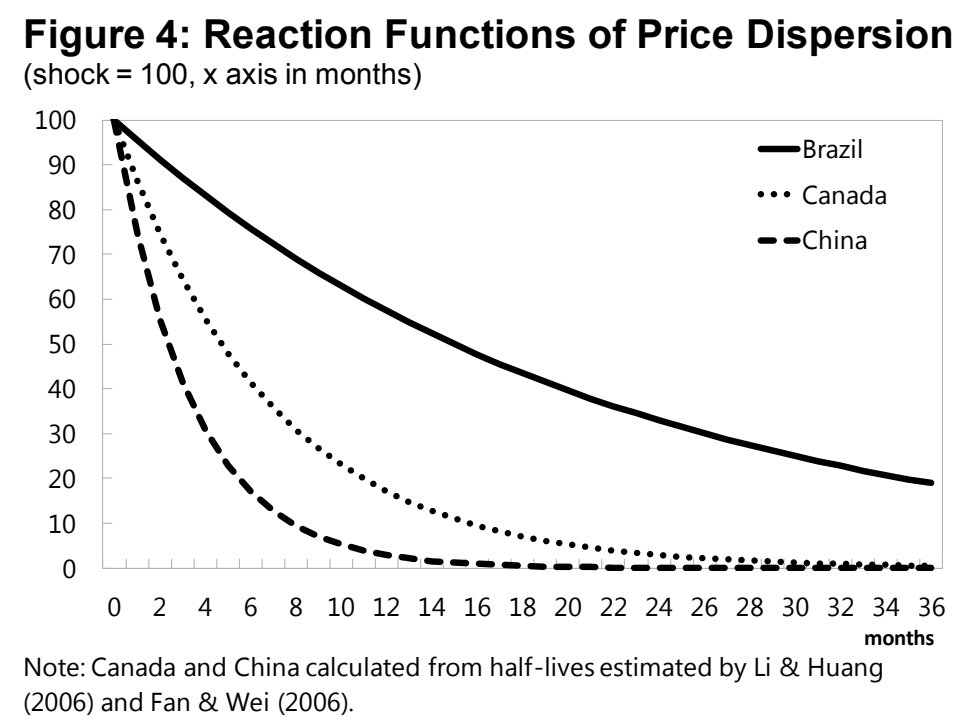

\section{Conclusions}

We found mixed evidence for domestic market integration in Brazil. LOOP is found to hold for most tradable products and, non-surprisingly, non-tradable products are found to be less likely to satisfy the law of one price. While consistent with evidence found for other countries, our evidence suggests price convergence occurs very slowly in Brazil. This suggests limited domestic market integration and highlights the need for improvements in infrastructure to improve the efficiency and productivity. We also found divergence in the speed of convergence across metro-areas, which may be a useful avenue for future research. 


\section{References}

Fan, C. Simon, and X. Wei, 2006, "The Law of One Price: Evidence from the Transitional Economy of China," The Review of Economics and Statistics, Vol. 88, No. 4, pp. 682-97.

Garcia-Escribano, Mercedes, C. Góes, and I. Karpowicz, 2015, "Filling the Gap: Infrastructure Investment in Brazil," IMF Working Paper 15/180 (Washington: International Monetary Fund).

Im, Kyung So, M. Hashem Pesaran, and Y. Shin, 2003, “Testing for Unit Roots in Heterogeneous Panels," Journal of Econometrics, Vol. 115, Issue 1, July, pp. 53-7.

Levin, Andrew, Chien-Fu Lin and J. Chu, 2002, "Unit Root Tests in Panel Data: Asymptotic and Finite-Sample Properties," Journal of Econometrics, Elsevier, Vol. 108 (January), pp. 1-24.

Li, Na, and J. Huang, 2006, "Price Convergence and Market Integration: Strong Evidence Using Canada Data,” Emp. Econ. Lett., Vol. 5 (January), No. 13, pp. 13-28.

Parsley, David, and Shang-jin Wei, 1996, "Convergence to the Law of One Price Without Trade Barriers or Currency Fluctuations”, Quarterly Journal of Economics, Vol. 111 (April), pp. 1211-36. 